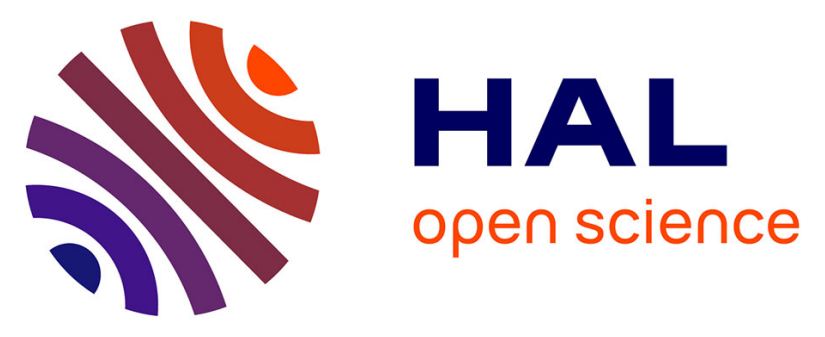

\title{
Prediction of the edaphic factors influence upon the copper and cobalt accumulation in two metallophytes using copper and cobalt speciation in soils
}

Bastien Lange, Michel-Pierre Faucon, Pierre Meerts, Mylor Shutcha, Grégory Mahy, Olivier Pourret

\section{To cite this version:}

Bastien Lange, Michel-Pierre Faucon, Pierre Meerts, Mylor Shutcha, Grégory Mahy, et al.. Prediction of the edaphic factors influence upon the copper and cobalt accumulation in two metallophytes using copper and cobalt speciation in soils. Plant and Soil, 2014, 379 (1-2), pp.275-287. 10.1007/s11104014-2068-y . hal-02265597

\section{HAL Id: hal-02265597 \\ https://hal.science/hal-02265597}

Submitted on 10 Aug 2019

HAL is a multi-disciplinary open access archive for the deposit and dissemination of scientific research documents, whether they are published or not. The documents may come from teaching and research institutions in France or abroad, or from public or private research centers.
L'archive ouverte pluridisciplinaire HAL, est destinée au dépôt et à la diffusion de documents scientifiques de niveau recherche, publiés ou non, émanant des établissements d'enseignement et de recherche français ou étrangers, des laboratoires publics ou privés. 
1 Authors: Bastien Lange ${ }^{1,2, *}$ - Michel-Pierre Faucon ${ }^{1}$ - Pierre Meerts ${ }^{2}$ - Mylor Shutcha ${ }^{4}$ -

2 Grégory Mahy ${ }^{3}$ - Olivier Pourret ${ }^{1}$

3

4 Prediction of the edaphic factors influence upon the copper and cobalt accumulation in

5 two metallophytes using copper and cobalt speciation in soils

6

$7 \quad{ }^{1}$ HYdrISE (Hydrogeochemistry Interactions Soil Environment) unit, UP.2012.10.102, Institut

8 Polytechnique LaSalle Beauvais (ISAB-IGAL), 19 rue Pierre Waguet, FR-60026 Beauvais,

9 France

10

${ }^{2}$ Laboratory of Plant Ecology and Biogeochemistry, Université Libre de Bruxelles, 50 Avenue F. Roosevelt, BE-1150 Brussels, Belgium

${ }^{3}$ Departement of Forest, Nature and Landscape, Biodiversity and Landscape Unit, Gembloux Agro-Bio Tech, University of Liège, 2 Passage des Déportés, BE-5030 Gembloux, Belgium

${ }^{4}$ Université de Lubumbashi, Faculté des Sciences Agronomiques, Lubumbashi, Democratic Republic of Congo

*Corresponding author: bastien.lange2@1asalle-beauvais.fr ; bastien.lange@ulb.ac.be 1 
Key-words chemical speciation, copper, cobalt, hyperaccumulation, metal availability, WHAM 6.

Abstract

Background and Aims Among the unique flora on copper and cobalt rich soils, some species are able to hyperaccumulate the $\mathrm{Cu}$ and $\mathrm{Co}$ in their shoots, however, the unexplained high variations of $\mathrm{Cu}$ and $\mathrm{Co}$ concentrations in shoots have been highlighted. A good comprehension of the $\mathrm{Cu}$ and $\mathrm{Co}$ accumulation variations would go through a characterization of the $\mathrm{Cu}$ and $\mathrm{Co}$ speciation in soils. We examined the covariations of $\mathrm{Cu}$ and $\mathrm{Co}$ speciation in soils and $\mathrm{Cu}$ and $\mathrm{Co}$ concentrations in plants.

Methods Plant samples of two species and soil samples $(\mathrm{n}=146)$ were collected in seven pedogeochemically contrasted sites. $\mathrm{Cu}$ and $\mathrm{Co}$ speciation in soils was modeled by WHAM 6.0.

Results Variation in copper accumulation in plant shoots were mostly influenced by $\mathrm{Cu}$ adsorbed by the $\mathrm{Mn}$ and $\mathrm{Fe}$ oxides fractions, whereas Co accumulation variations were strongly influenced by Co free and Co adsorbed by the $\mathrm{OM}$ and $\mathrm{Fe}$ fractions.

Conclusions Availability of $\mathrm{Cu}$ and $\mathrm{Co}$ seems to be species-specific and is not explained only by the free $\mathrm{Cu}$ and Co content in the soil solution, but also strongly by the part linked to colloidal fractions. Availability of $\mathrm{Cu}$ and Co is a complex mechanism, closely related to all the biogeochemical processes which occur in the rhizosphere. Future work should perform experiments in controlled conditions to examine the soil parameters that influence the $\mathrm{Cu}$ and $\mathrm{Co}$ availability.

Abbreviations

50

MnOX = manganese oxides

$\mathrm{FeOx}=$ iron oxides

$\mathrm{HM}=$ humic material

$\mathrm{OM}=$ organic matter

$-\mathrm{MnOx}=$ bound to manganese oxides

$-\mathrm{FeOx}=$ bound to iron oxides

$-\mathrm{OM}=$ bound to organic matter

$\mathrm{SD}=$ standard deviation 


\section{Introduction}

Soils contaminated by metals represent an important constraint for vegetation. Only a few species tolerate soil metal concentrations up to 1,000 times higher than the concentration usually found in normal soils (Ernst 1974; Reeves and Baker 2000). Some of these, called hyperaccumulators, are able to concentrate metal in their shoot up to extremely high concentrations (Baker 1981; Macnair 2003; Krämer 2010; Rascio and NavariIzzo 2011). For two decades, hyperaccumulator species have attracted much attention because of their potential use as a phytoextraction strategy. According to the recent literature, species would be considered as $\mathrm{Cu}$ and $\mathrm{Co}$ hyperaccumulators when the metal concentration in shoots exceeds $300 \mathrm{mg} \cdot \mathrm{kg}^{-1}$, without toxicity symptoms and growth inhibition (Krämer 2010; Van der Ent et al. 2013). Although Macnair (2003) suggests that Cu hyperaccumulation has not yet been observed in control conditions, Küpper et al. (2009) found that Crassula helmsii growing in hydroponic conditions could accumulate more than $9,000 \mathrm{mg} \cdot \mathrm{kg}^{-1}$ in shoot when the nutrient solution was enriched with less than $1 \mathrm{mg} \cdot \mathrm{kg}^{-1} \mathrm{Cu} 2+$. Only a few species around the world (mostly Brassicaceae), are considered as constitutive hyperaccumulators. These species show that all populations have very high foliar metal concentrations irrespective of metal concentration in soil, including Noccaea caerulescens (Dechamps et al. 2007), Arabidopsis halleri (Frerot et al. 2010) and Gomphrena claussenii (Villafort Carvalho et al. 2013) (zinc and cadmium hyperaccumulators); as well as several Alyssum species (nickel hyperaccumulator) (Brooks and Radford 1978; Brooks et al. 1979; Broadley et al. 2001; Hanikenne and Nouet 2011). Most of metallophytes are defined as facultative hyperaccumulators, which means that populations or individuals are hyperaccumulators and some are not (Pollard et al. 2002).

Plants which accumulate $\mathrm{Cu}$ and $\mathrm{Co}$ in their shoots are rare and most of them occur in Katanga (Dem. Rep of Congo) (Reeves and Baker 2000; Reeves 2006). In this region of South Central Africa, a species-rich vegetation is associated to natural outcrops of $\mathrm{Cu}$ and $\mathrm{Co}$ enriched bedrocks, including cuprophytes (Duvigneaud 1958; Duvigneaud and Denaeyer-De Smet 1963; Ernst 1974; Ernst 1990; Faucon et al. 2012a; Ilunga wa Ilunga et al. 2013) and cobaltophytes (Duvigneaud 1959; Faucon et al. 2010; Saad et al. 2012; Seleck et al. 2013). Ecology and evolution of copper and cobalt tolerance and accumulation in this vegetation is still misunderstood, due to high inter- and intraspecific variations of the $\mathrm{Cu}$ and $\mathrm{Co}$ shoot concentrations. Unusually high shoot $\mathrm{Cu}$ and Co concentrations reported in earlier studies may result from surface contamination by soil particles and, therefore, plant materials from metal-rich soils should be washed prior to analysis (Faucon et al. 2007; Van der Ent et al. 2013). Copper in shoots ranges from 80 to $1,400 \mathrm{mg} \cdot \mathrm{kg}^{-1}$ and from 330 to $1,200 \mathrm{mg} \cdot \mathrm{kg}^{-1}$ for Crepidorhopalon perennis and Anisopappus chinensis, respectively (Faucon et al. 2007; Faucon et al. 2009a). In 
the same study, for Co, both species had shoot concentrations that ranged from 61 to $1,105 \mathrm{mg} \cdot \mathrm{kg}^{-1}$ and from 933 to $1,948 \mathrm{mg} \cdot \mathrm{kg}^{-1}$, respectively. Such variations have a genetic origin for $\mathrm{Cu}$, especially due to genetic differentiations among populations, as demonstrated by cultivation in uniform conditions (Faucon et al. 2012b). However, high inter- and intra-population phenotypic variations in $\mathrm{Cu}$ and $\mathrm{Co}$ shoot concentration suggest a diversity of accumulation responses and an influence of edaphic parameters upon $\mathrm{Cu}$ and $\mathrm{Co}$ accumulation by plants. A good understanding of the $\mathrm{Cu}$ and $\mathrm{Co}$ accumulation variations would go through an accurate characterization of the soil-root interface properties and mechanisms, controlling metal availability. The influence of soil upon metal accumulation by plants can be studied in experimental conditions, by using a metal contamination gradient in the substrate, but this approach has limits and can be criticized due to differences with the in nature soil properties (e.g. Van der Ent et al. 2013). In such an approach, Cu hyperaccumulation is poorly expressed (Morrison et al. 1979, 1981; Chipeng et al. 2010; Faucon et al. 2012) and variations could not be distinguished from substrate differences (Escarre et al. 2013). Another approach could identify the relationship between metal concentrations in soils and in shoots by studying populations from pedogeochemically contrasted sites. Ecological studies have commonly used total metal concentrations or extractable metal concentrations determined at a fixed $\mathrm{pH}$ value (AcNH4EDTA 1M pH=4.65) (Brun et al. 1998; Faucon et al. 2009). In this way, $\mathrm{pH}$ variations are not considered, while it highly influences metal mobility (Alloway 1995; McLaren and Crawford 1973; Kabata-Pendias and Pendias 2001; Chaignon et al. 2002; Faucon et al. 2011). It is important to include soil $\mathrm{pH}$, due to the direct impact of the $\mathrm{Cu}$ and $\mathrm{Co}$ speciation upon the $\mathrm{Cu}$ and $\mathrm{Co}$ uptake by plant (Poschenreider et al. 2001; Krishnamurti and Naidu 2002; Chaignon et al. 2002).

By considering soil $\mathrm{pH}$, organic matter content and total concentrations of several elements in soil, chemical speciation modeling appears to be an interesting tool to investigate the relationships between soil properties and metal accumulation in plants. Using speciation calculation codes including chemical constants and equilibrium, these methods can assess metal fractionation in soils. Windermere Humic Aqueous Model (WHAM) (Tipping 1998; Pourret et al. submitted) can be used to calculate metal fractionation, and thus, estimate the bound to $\mathrm{MnOx}, \mathrm{FeOx}$ and $\mathrm{OM}$ metal concentrations, as well as the free metal concentration (i.e. ionic form) in a soil sample. To understand $\mathrm{Cu}$ and $\mathrm{Co}$ accumulation variations, inclusion of the essential soil parameters controlling $\mathrm{Cu}$ and $\mathrm{Co}$ mobility in soils is necessary: $\mathrm{pH}$, redox potential, $\mathrm{OM}$ quality and quantity, oxides, clays, sulphides and carbonates (Kabata-Pendias and Pendias 2001). These factors may partly control $\mathrm{Cu}$ and $\mathrm{Co}$ availability, by influencing the equilibrium between total and available metal concentration in soils. However, predicting the availability of metals, especially in contaminated environments, is still very difficult (Hinsinger 
and Courchesne 2008). Key role of root-induced processes on soil constituents' mobility (Harter and Naidu 2001; Hinsinger 2001; Adriano et al. 2004; Houben and Sonnet 2012) as well as rhizosphere chemistry and microbiology (Wenzel 2009; Alford et al. 2010) increases the complexity of metal availability. Mobility and availability of metals at the soil root-interface need to be investigated and to date, there is no universal method to estimate the metal availability to plants and soil organisms (Nolan et al. 2003). It has however been established that the metal concentration in the soil solution would be the only fraction directly available for plant uptake (Fageria et al. 1991; Marschner 1995; Whitehead 2000).

In the present study, speciation modeling is used to investigate the relationships between $\mathrm{Cu}$ and $\mathrm{Co}$ accumulation by plants and $\mathrm{Cu}$ and $\mathrm{Co}$ chemical forms in soil. Aims were to (i) examine variations of $\mathrm{Cu}$ and $\mathrm{Co}$ speciation in soils and $\mathrm{Cu}$ and $\mathrm{Co}$ concentrations among plant populations, (ii) determine which edaphic factors and $\mathrm{Cu}$ and $\mathrm{Co}$ fractions influence the $\mathrm{Cu}$ and $\mathrm{Co}$ accumulation in plants, and (iii) compare the responses for two different species. Several hypotheses can be suggested: (i) variations in the $\mathrm{Cu}$ and Co speciation would explain the $\mathrm{Cu}$ and $\mathrm{Co}$ shoot concentration variations; (ii) the mobile $\mathrm{Cu}$ and $\mathrm{Co}$ concentration in soils would explain accumulation variations.

\section{Materials and methods}

\section{Plant populations}

Two model species have been selected in the study. Crepidorhopalon tenuis (S. Moore) Fischer (Linderniaceae) is a pseudometallophyte, $\mathrm{Cu}$ and Co hyperaccumulator species (Faucon et al. 2009). It is an annual species colonizing recently disturbed mine deposits. Anisopappus chinensis (L.) Hook.f. \& Arn. (Asteraceae) is also a pseudometallophyte. It is a short-lived perennial found in relatively closed steppic savanna on stabilised contaminated substrates (Ilunga wa ilunga et al. 2013; Seleck et al. 2013). Large variations of $\mathrm{Cu}$ and $\mathrm{Co}$ concentrations in shoots of this species have already been highlighted (Faucon et al. 2007). Four populations of both species were selected in different sites, in the Katanga region (Dem. Rep. of Congo), as described in Table 1. Two populations of $C$. tenuis were sampled on the anthropogenically disturbed sites Ruashi (Ru) (recolonization of mine deposits) and Vallée Karavia (VK) (Cu-Co atmospheric fall-out contamination) and two naturally occurring populations in the $\mathrm{Cu}-\mathrm{Co}$ hills locally disturbed by reworked substrate (artisanal mining): Niamumenda (Nm) and Kalabi (Ka). The four populations of $A$. chinensis have been sampled on two natural $\mathrm{Cu}-$ 
Co undisturbed hills from the Tenke-Fungurume region: Fungurume5 (F5) and Goma2 (G2), and two disturbed

$\mathrm{Cu}-\mathrm{Co}$ hills in the Lubumbashi region: Mine de l'Etoile (E) and Niamumenda (Nm).

Sampling and samples preparation

In each site, 20 plants (whole shoot) and 20 soil samples from the rhizosphere of each plant $(0-15 \mathrm{~cm})$ were collected. Study populations were carefully delimited and sampling was carried out systematically across the sites, covering the soil heterogeneity in each site. Plants were collected at the same development stage. Sampling of C. tenuis occurred in April 2006 and 2007 and sampling for A. chinensis occurred during March and April 2012. A total of 146 plant and soil samples were considered in this study.

After harvesting, plants were carefully brushed (whole shoots), washed with Alconox ${ }^{\circledR} 1 \%$ in demineralized water, dried at $60^{\circ} \mathrm{C}$ for $48 \mathrm{~h}$ (Faucon et al. 2007) and weighted. Soil samples were dried at room temperature, sieved ( $2 \mathrm{~mm})$ and ground in a mill (RETSCH RM 200).

Plant and soil analysis

The Crepidorhopalon tenuis samples were mineralized by dry ashing in a muffle furnace at $550^{\circ} \mathrm{C}$ for $12 \mathrm{~h}$. Ash was dissolved in $\mathrm{HCl}$. The samples were then analyzed by Inductively Coupled Plasma Optical Emission Spectrometry (ICP-OES) (Varian Vista MPX) to determine $\mathrm{Cu}-\mathrm{Co}$ concentration in shoot. To determine Cu-Co concentration in shoot of A. chinensis two steps were performed. A mass of shoot were digested using a mixture of $8 \mathrm{~mL} \mathrm{HNO}_{3}$ and $2 \mathrm{~mL} \mathrm{HCl}$ (Avula et al. 2010) with a low pressure mineralization (Lavilla et al. 2009). Vessels containing the mix were placed in a Mars 5 microwave (Microwave Accelerated Reaction System CEM corporation, USA) according to the Avula et al. (2010) treatment. Then, $\mathrm{Cu}$ and Co concentrations in samples were determined by Inductively Coupled Plasma Mass Spectrometry (ICP-MS) (Thermo Scientific XSERIES2). Quantitative analyses were carried out by external calibration (eight points) by using mono- and multi-element standard solutions (Accu Trace Reference, USA). Indium was used as an internal standard at a concentration of $100 \mu \mathrm{g} . \mathrm{L}^{-1}$ in order to correct for instrumental drift and matrix effects. The measurement bias for the determination of the concentration of $\mathrm{Cu}$ and $\mathrm{Co}$ was assessed by the analysis of the SRM1573a certified reference material (tomato leaves: Gills 1995). Typical uncertainties including all error sources are below $\pm 5 \%$ 
$(\mathrm{OM})$ content by loss on ignition $\left(500^{\circ} \mathrm{C}\right.$ for $\left.8 \mathrm{~h}\right)$. Soil chemical analyses were performed by Acme Analytical Laboratories Ltd. (Vancouver Canada), accredited under ISO 9002. The considered analyzed elements were Co, $\mathrm{Cu}, \mathrm{Fe}, \mathrm{Mn}, \mathrm{Zn}, \mathrm{K}, \mathrm{Mg}, \mathrm{Al}, \mathrm{Ca}$. Soil samples were digested using a strong multi-acid method that dissolves most minerals. Then, $0.25 \mathrm{~g}$ split was heated in $\mathrm{HNO}_{3}-\mathrm{HClO}_{4}-\mathrm{HF}$ to fuming and taken to dryness. The residue was further dissolved in $\mathrm{HCl}$ and solutions were analyzed using ICP-MS.

\section{Chemical speciation calculations}

WHAM 6 (version 6.0.10) was used to calculate $\mathrm{Cu}$ and Co speciation. Predictions for the equilibrium metal binding by environmental colloids made for the present study were done using the combined WHAM-SCAMP speciation code. WHAM-SCAMP is able to provide a full description of solid-solution speciation by incorporating two main codes: (i) the Windermere Humic Aqueous Model (WHAM) to calculate the equilibrium solution speciation (Tipping 1994), and (ii) the Surface Chemistry Assemblage Model for Particles (SCAMP) to calculate the binding of protons and metals by natural particulate matter (Lofts and Tipping 1998). The code for the WHAM model incorporates a number of submodels: Humic Ion-Binding Model 6 and a description of inorganic solution chemistry, cation exchange by clays, the precipitation of aluminium and iron oxyhydroxides, and adsorption-desorption of fulvic acids. The SCAMP model consists of three submodels: (i) Humic IonBinding Model 6, (ii) a SCM describing proton and metal binding to oxides (e.g., MnOx or FeOx), and (iii) a model describing the electrostatic exchange of cations on clays. Three binding phases were examined: $\mathrm{MnOx}$, FeOx, and Humic Material (HM). The X-Ray diffraction revealed that MnOx and $\mathrm{FeOx}$ are respectively pyrolusite and a mix hematite-goethite. The concentration of HM were derived from the experimental OM measurements: $50 \%$ of the OM measured in the field samples was assumed to be HM, themselves being defined as $100 \%$ fulvic acid. Saturation index and mineral precipitation were not considered; which could be a limitation of this approach (Pourret et al. submitted).

Input data for the $\mathrm{Cu}$ and $\mathrm{Co}$ speciation determination were total concentrations of $\mathrm{Cu}, \mathrm{Co}, \mathrm{Mg}, \mathrm{Ca}, \mathrm{Mn}, \mathrm{Fe}, \mathrm{K}$, $\mathrm{Zn}, \mathrm{pH}$ of soils and $\mathrm{OM}$ content. A speciation calculation was achieved for the 160 soil samples. In this study, the term free was used to qualify the $\mathrm{Cu}$ and $\mathrm{Co}$ modeling output mobile fraction, considered as the ionic fraction. Sulphates and carbonates were not considered.

\section{Statistical analysis}


Descriptive statistics were performed on total soil analysis and normality of data and homogeneity of variances were verified. One way ANOVA (Analysis of Variance) tested differences in $\mathrm{Cu}$ and Co concentrations in shoots among populations and differences in $\mathrm{Cu}$ and $\mathrm{Co}$ fractionation among sites. Significance was defined and represented as follow: $* * *: p<0.001, * *: p<0.01, *: p<0.05$, NS=non-significant. Post-hoc multiple comparisons (Tukey HSD) have been applied to compare populations from each other and $\mathrm{Cu}$-Co fractions resulting from speciation modeling from each other. The relationship between element concentration in plants and edaphic factors (concentrations of $\mathrm{Cu}, \mathrm{Co}, \mathrm{Mn}, \mathrm{Fe}, \mathrm{Mg}, \mathrm{Ca}, \mathrm{OM}(\%), \mathrm{pH}$ and the binding phases from speciation modeling results) were characterized with Pearson correlations.

\section{Results}

Results of $\mathrm{Cu}$ and $\mathrm{Co}$ fractionation are presented in Table 2. Total $\mathrm{Cu}$ and $\mathrm{Co}$ concentrations showed differences between sites $\left(\mathrm{F}_{(6,147)}=7.65, \mathrm{p}<0.001\right.$ and $\mathrm{F}_{(6,147)}=14.26, \mathrm{p}<0.001$, respectively). There were significant differences between $\mathrm{Cu}$ fractions for each site (Tab. 2). For $\mathrm{Cu}$, the two largest fractions were $\mathrm{Cu}$ bound to $\mathrm{OM}$ $(\mathrm{Cu}-\mathrm{OM})$ and to $\mathrm{FeOx}(\mathrm{Cu}-\mathrm{FeOx})$. The free $\mathrm{Cu}$ concentration varied from $0.7 \%$ to $18.8 \%$ of the total $\mathrm{Cu}$ concentration. Copper was mainly bound to $\mathrm{FeOx}$ and OM. Significant differences for each $\mathrm{Cu}$ fraction existed between sites (Tab. 2). The highest concentrations of $\mathrm{Cu}-\mathrm{FeOx}$ were found in $\mathrm{Nm}$ and $\mathrm{E}$ (69\% of total $\mathrm{Cu}$ ) where mean total Fe concentration reached 48,500 mg. $\mathrm{kg}^{-1}$ and $42,300 \mathrm{mg} \cdot \mathrm{kg}^{-1}$, respectively. Samples from VK were characterized by low total $\mathrm{Fe}$ and Mn contents (respectively mean $=19,610 \pm 9,654 \mathrm{mg} \cdot \mathrm{kg}^{-1}$; and mean $=65 \pm 37$ mg. $\left.\mathrm{kg}^{-1}\right)$ and high $\mathrm{OM}$ content $($ mean $=9.38 \% \pm 4.2 \%)$. At this site, the fraction of $\mathrm{Cu}$ bound to FeOx was the lowest while the fraction of $\mathrm{Cu}$ bound to $\mathrm{OM}$ was the highest (respectively mean $=15 \%$ and $81.8 \%$ of total $\mathrm{Cu}$ ). There were significant differences between Co fractions for each site (except samples from E) (Tab. 2). Cobalt was predominantly free and bound to $\mathrm{MnOx}(\mathrm{Co}-\mathrm{MnOx})$ in soils. The free Co fraction was higher than the free $\mathrm{Cu}$ one for each site (meanly from 28.1 to $69.4 \%$ of total $\mathrm{Co}$ ). Significant differences for each Co fraction existed between sites. Nm was characterized by the highest Mn content in soil (mean = 5,700 mg. $\left.\mathrm{kg}^{-1}\right)$. At this site, the Co-MnOx concentration was the highest (mean $=71.1 \%$ of total Co). At VK, site where $\mathrm{Mn}$ 
concentration was the lowest, Co was mainly bound to OM (meanly 53.8\% of total Co). At this site, the Co$\mathrm{MnOx}$ concentration was the lowest $($ mean $=5.8 \%$ of total $\mathrm{Co})$.

\section{$\mathrm{Cu}$ and Co accumulation in plants}

Results of $\mathrm{Cu}$ and $\mathrm{Co}$ concentrations in shoots showed large variations between species and populations (Fig. 1). For $\mathrm{Cu}, 22$ of 79 samples of A. chinensis and 25of 67 samples of C. tenuis accumulated more than 300 mg.kg (range: $4-2,821 \mathrm{mg} \cdot \mathrm{kg}^{-1}$ and $34-2,524 \mathrm{mg} \cdot \mathrm{kg}^{-1}$ for A. chinensis and C. tenuis, respectively). For Co, 26 of 79 samples of A. chinensis and 2 of 67 samples of C. tenuis accumulated more than $300 \mathrm{mg} \cdot \mathrm{kg}^{-1}$ (range: 3 1,334 mg. $\mathrm{kg}^{-1}$ and 8 - $605 \mathrm{mg} \cdot \mathrm{kg}^{-1}$ for A. chinensis and C. tenuis, respectively).

Large $\mathrm{Cu}$ and $\mathrm{Co}$ accumulation variations existed among populations of both species (for $\mathrm{Cu}, \mathrm{F}_{(7,145)}=$ 7.1, $\mathrm{p}<0.001$; for $\left.\mathrm{Co}, \mathrm{F}_{(7,145)}=17.6, \mathrm{p}<0.001\right)$. Population $\mathrm{F} 5$ of A. chinensis had the highest Co shoot concentration (mean $\left.=1,089 \pm 768 \mathrm{mg} \cdot \mathrm{kg}^{-1}\right)\left(\mathrm{F}_{(7,145)}=19.2, \mathrm{p}<0.001\right)$. Strikingly low concentrations of Co in plant shoots $\left(<20 \mathrm{mg} \cdot \mathrm{kg}^{-1}\right)$ were found in the $\mathrm{Nm}$ site for both species. On the contrary, that site yielded the highest shoot $\mathrm{Cu}$ accumulation for both species (A. chinensis, range: $104-1,335 \mathrm{mg} \cdot \mathrm{kg}^{-1}$, mean $=455 \mathrm{mg} \cdot \mathrm{kg}^{-1}$ and $C$. tenuis, range: $84-2,525 \mathrm{mg} \cdot \mathrm{kg}^{-1}$, mean $\left.=673 \mathrm{mg} \cdot \mathrm{kg}^{-1}\right)\left(\mathrm{F}_{(7,145)}=125.4, \mathrm{p}<0.001\right)$.

\section{Relationships between edaphic factors and $\mathrm{Cu}$ and Co accumulation in shoot}

Correlations between soil fractions and shoot accumulation were element- and species- dependent (Tab. 3, Fig. 2), however, some general patterns emerged. Correlations between total $\mathrm{Cu}$ soil content and shoot $\mathrm{Cu}$ concentration were positive for $C$. tenuis $(\mathrm{r}=0.51, \mathrm{p}<0.001)$ and non-significant for A. chinensis (Fig. 2a). Total Co soil content was positively correlated with shoot Co concentration for A. chinensis and C. tenuis ( $\mathrm{r}=0.77$, $\mathrm{p}<0.001$ and $\mathrm{r}=0.45, \mathrm{p}<0.001$, respectively) (Fig. $2 \mathrm{~b}$ ). No correlations occurred between $\mathrm{pH}$ and shoot Co concentration for both species. On the contrary, $\mathrm{pH}$ was positively correlated with $\mathrm{Cu}$ concentration in shoots for C. tenuis $(\mathrm{r}=0.40, \mathrm{p}<0.001)$ but not significant for A. chinensis. Organic matter soil content was negatively correlated with shoot $\mathrm{Cu}$ concentration for both species. Positive correlation have been observed between OM soil content and shoot Co concentration for A. chinensis $(\mathrm{r}=0.57, \mathrm{p}<0.001)$ but not significant for $C$. tenuis. Shoot $\mathrm{Cu}$ concentration was correlated with total $\mathrm{Mn}$ soil content for A. chinensis and C. tenuis $(\mathrm{r}=0.51, \mathrm{p}<0.001$ and $\mathrm{r}=0.65, \mathrm{p}<0.001$, respectively). However, the strong negative correlation between total Mn soil content and shoot 
Co concentration for A. chinensis $(\mathrm{r}=-0.65, \mathrm{p}<0.001)$ was not verified for $C$. tenuis. A positive correlation was established between total Fe soil content and shoot $\mathrm{Cu}$ concentration for A. chinensis $(\mathrm{r}=0.42, \mathrm{p}<0.001)$, but not for C. tenuis. A negative correlation occurred between total Fe soil content and Co concentration in shoot for $A$. chinensis $(\mathrm{r}=0.5, \mathrm{p}<0.001)$. This relationship was not verified for $C$. tenuis. A positive correlation was observed between free $\mathrm{Cu}$ concentration and shoot $\mathrm{Cu}$ concentration for $C$. tenuis ( $\mathrm{r}=0.50, \mathrm{p}<0.001)$, but not for A. chinensis $(\mathrm{r}=0.49, \mathrm{p}<0.05)$ (Fig. 2c). Free Co concentration was positively correlated with shoot Co concentration for A. chinensis and C. tenuis $(\mathrm{r}=0.8, \mathrm{p}<0.001$ and $\mathrm{r}=0.57$, $\mathrm{p}<0.001$, respectively) (Fig. 2d). For $\mathrm{Cu}$, the highest correlation was observed between $\mathrm{Cu}$ bound to $\mathrm{MnOx}(\mathrm{Cu}-$ MnOx) soil concentration and shoot $\mathrm{Cu}$ concentration for A. chinensis and C. tenuis $(\mathrm{r}=0.39, \mathrm{p}<0.001$ and $\mathrm{r}=0.76, \mathrm{p}<0.001$, respectively) (Fig. 2e). However, $\mathrm{Cu}-\mathrm{FeOx}$ soil concentration was also positively correlated with shoot $\mathrm{Cu}$ concentration for both species. This latter concentration was negatively correlated with shoot Co concentration for A. chinensis. For Co, the highest correlation was observed between Co bound to OM (Co-OM) soil concentration and shoot Co concentration for A. chinensis and C. tenuis ( $\mathrm{r}=0.9, \mathrm{p}<0.001$ and $\mathrm{r}=0.64$, $\mathrm{p}<0.001$, respectively) (Fig. 2f). A positive correlation was also observed between Co bound to $\mathrm{FeOx}$ (Co-FeOx) soil concentration and shoot Co concentration for both species.

\section{Discussion}

$\mathrm{Cu}$ and Co speciation in soils

Copper appeared to have a strong affinity for $\mathrm{FeOx}$ and $\mathrm{OM}$ which would explain the low free $\mathrm{Cu}$ concentrations in soils compared to other $\mathrm{Cu}$ fractions. In normal soils, copper co-adsorbs with $\mathrm{Mn}$ and $\mathrm{Fe}$ oxides (McLaren and Crawford 1973). Copper was fixed by OM when total Fe content was low (VK). An increase in the total $\mathrm{Fe}$ content $(\mathrm{E}, \mathrm{Nm}, \mathrm{Ka})$ resulted in an increase of the $\mathrm{Cu}-\mathrm{FeOx}$ concentration. This suggests that $\mathrm{Fe}$ oxides are potentially major competitors of $\mathrm{OM}$ for $\mathrm{Cu}$ speciation.

Our results showed that cobalt had a particular affinity with Mn oxides (Tab. 2). This is in agreement with the literature which highlights that cobalt is adsorbed at the surface of Mn oxides (Childs 1975; Li et al. 2004; Tontgavee et al. 2005; Luo et al. 2010). Sites with the lowest Mn soil content exhibited major Co free and 

concentration in soils showed the highest Co-OM concentration. Organic matter appears to be a major competitor of Mn oxides for Co speciation (Collins and Kinsela 2010, Collins and Kinsela 2011). Free Co concentration is higher, in percentage, than free $\mathrm{Cu}$ concentration, relative to the other $\mathrm{Co}$ or $\mathrm{Cu}$ fractions (Tab. 2). This could be explained by the stronger capacity to complex with colloids for $\mathrm{Cu}$, compared to $\mathrm{Co}$. Indeed, the sequence of complex stability of transition metals, known as the Irving Williams series, is typically $\mathrm{Co}^{2+}<\mathrm{Ni}^{2+}<\mathrm{Cu}^{2+}<\mathrm{Zn}^{2+}$ (Stumm and Morgan 1996). Organic matter content seems to have a strong influence upon metal fractionation, which confirms results obtained by Pourret et al. (2007). It can be assumed that mobile and non-mobile $\mathrm{Cu}$ and $\mathrm{Co}$ fractions vary among sites and seem to be closely related to the $\mathrm{MnOx}$ and $\mathrm{FeOx}$ concentrations, the $\mathrm{OM}$ content and the soil $\mathrm{pH}$. High variability of $\mathrm{Cu}$ and $\mathrm{Co}$ speciation in soils has been observed, which would involve variations of the $\mathrm{Cu}$ and $\mathrm{Co}$ availability.

\section{Variations of $\mathrm{Cu}$ and Co concentrations in shoots among populations}

Results confirm that A. chinensis and C. tenuis are facultative $\mathrm{Cu}$ and Co hyperaccumulators (Faucon et al. 2009), characterized by a high variation of $\mathrm{Cu}$ and $\mathrm{Co}$ shoot concentrations. For $\mathrm{Cu}$ and $\mathrm{Co}$ respectively, 17\% and $21 \%$ of plants of A. chinensis and $17 \%$ and $2 \%$ of plants of C. tenuis have been recorded with a concentration in shoots of up to $300 \mathrm{mg} \cdot \mathrm{kg}^{-1}$, i.e. the hyperaccumulation threshold (Van der Ent et al. 2013), without showing any toxicity symptoms or growth inhibition.

The phenotypic accumulation variations would be associated with specific soil conditions. Interpopulation variations of $\mathrm{Cu}$ and $\mathrm{Co}$ accumulation in plant shoots would not only be explained by variations of the total and free $\mathrm{Cu}$ and $\mathrm{Co}$ soil content. The variation of edaphic factors, and especially the $\mathrm{OM}$ and total $\mathrm{Fe}$ content, could explain the $\mathrm{Cu}$ accumulation variability among populations of both species. The high $\mathrm{Cu}-\mathrm{OM}$ and $\mathrm{Cu}-\mathrm{FeOx}$ concentration seem to limit the $\mathrm{Cu}$ uptake in populations of both species (Fig. 1, Tab. 2). For Co, the high $\mathrm{Co}-\mathrm{MnOx}$ concentration at $\mathrm{Nm}$ compared to the other Co fractions could explain the lowest $\mathrm{Co}$ accumulation observed for the two species (Fig. 1, Tab. 2). In this context, variations of $\mathrm{Cu}$ and $\mathrm{Co}$ accumulation among populations of A. chinensis and C. tenuis would correspond, not only to the genetic capacity to accumulate metal in shoots (Faucon et al. 2012), but also in part to edaphic context variations, especially $\mathrm{Cu}$ and 
in shoots with $\mathrm{Cu}$ and $\mathrm{Co}$ fractions in soils, to explain the $\mathrm{Cu}$ and $\mathrm{Co}$ shoot concentration variations observed in natura.

Relationships between $\mathrm{Cu}$ and Co speciation variations in soils and $\mathrm{Cu}$ and Co shoot accumulation variations

Results confirm the strong synergistic influence of soil total $\mathrm{Mn}$ content on $\mathrm{Cu}$ accumulation in cuprophytes and its antagonist effect on Co accumulation as shown by Faucon et al. (2009). Interestingly, total Fe content in soils seems to be a positive predictor of $\mathrm{Cu}$ accumulation for A. chinensis, the opposite effect seen in reygrass, a metal non-tolerant species ( $\mathrm{Li}$ et al. 2004). The $\mathrm{Cu}$ mobility in soil is known to be negatively correlated with $\mathrm{pH}$ (Kabata-Pendias and Pendias 2001). Therefore, the positive correlation between $\mathrm{Cu}$ accumulation in $C$. tenuis and soil $\mathrm{pH}$ in this study may be surprising. However, the range in $\mathrm{pH}$ values in our study is relatively restricted for $C$. tenuis soils (from 4.4 to 6.2 ) and it also appears that the correlation is driven mostly by one site (VK) which has relatively low $\mathrm{pH}$ and relatively low $\mathrm{Cu}$ accumulation in plants.

The differences of $\mathrm{Cu}$ and $\mathrm{Co}$ accumulation in shoot plants with respect to the variability of $\mathrm{Cu}$ and $\mathrm{Co}$ speciation in soils and following edaphic factors, $\mathrm{pH}, \mathrm{OM}$, total $\mathrm{Mn}$ and total Fe contents exist between both species. These differences may also suggest species-specific mechanisms of the $\mathrm{Cu}$ and Co availability, uptake and transport in the plant, and confirms the complexity of soil-plant processes (Hinsinger and Courchesne 2008).

The results showed the influence of $\mathrm{Cu}$ and $\mathrm{Co}$ speciation on the variability of $\mathrm{Cu}$ and $\mathrm{Co}$ accumulation in both species (Tab. 3). Copper accumulation in plant shoots were positively influenced by $\mathrm{Cu}-\mathrm{MnOx}$ and $\mathrm{Cu}-$ FeOx concentrations, whereas Co accumulation variations were strongly influenced by Co free and Co-OM and Co-FeOx concentrations. The Co-OM soil fraction seems to appear to be the most available Co fraction, in those soils for both species. Similarly, both Li et al. (2004) and McLaren et al. (1987) highlighted that organicallybound $\mathrm{Co}$ influenced $\mathrm{Co}$ availability to plants. Availability of $\mathrm{Cu}$ and $\mathrm{Co}$ does not seem to be strictly a result of the free $\mathrm{Cu}$ and $\mathrm{Co}$ concentrations in soils. Even if ionic species metal concentrations in soils would appear, by hypothesis, to be a good predictor of metal uptake concentration by plants, because of their direct availability (Fageria et al. 1991; Marschner 1995; Whitehead 2000), the bound to solid-phase fractions have to be considered for availability assessment. Indeed, some plants are able to mobilize and take up elements from the non-mobile solid fraction (Knight et al. 1997; Hinsinger et al. 2005). These significant influences of the solid phases upon the accumulation for both species could be explained by root-induced processes which could be responsible to pH changes (Marschner 1995; Hinsinger et al. 2003). Indeed, the soil solution acidification by root activity, may 
causes desorption of metals (Marschner 1995; Harter and Naidu 2001; Hinsinger et al. 2003) and thereby, increase the ionic form metal concentration. This study confirms that the availability of metals is closely related to all the biogeochemical processes which occur in the rhizosphere. Estimate of the available metal concentration in soils seem to be complex but the present study is the first attempt of $\mathrm{Cu}$ and $\mathrm{Co}$ availability assessment in metalliferous soils. Undertaking a laboratory experiment which simulates the field conditions would help unravel some of this complexity. For this, both species could be cultivated in growth-chamber, on homogeneous soil contaminated by defined $\mathrm{Cu}$ and $\mathrm{Co}$ concentrations, in which chemical factors influencing $\mathrm{Cu}$ and $\mathrm{Co}$ availability (pH, OM, MnOx, FeOx) would vary in controlled conditions (Chaignon and Hinsinger 2003). However, as microbial activities would also influence the availability of chemical elements in soil (Hinsinger et al. 2005) and the patterns of metal accumulation in plant species (Fomina et al. 2005; Toler et al. 2005; Barzanti et al. 2007; Kabagale et al. 2010) incorporating microbial activities in an experimental setting to test their effect on the variation of $\mathrm{Cu}$ and $\mathrm{Co}$ accumulation in pants would prove fruitful. Perspectives would be to integrate the study of influence of microbial activities on the variation of $\mathrm{Cu}$ and $\mathrm{Co}$ accumulation in plants.

Comprehension of the $\mathrm{Cu}$ and $\mathrm{Co}$ accumulation variations in plant shoots in situ and methods of phytoremediation of $\mathrm{Cu}$ and $\mathrm{Co}$ contaminated soils need therefore to be reassessed in the light of the present results.

\section{Acknowledgements}

The Polytechnic Institute LaSalle Beauvais (IPLB, Fr) and the Belgian Fund for Scientific Research (FRSFNRS) are acknowledged for financial support to Bastien Lange, who is a research fellow of the Fonds pour la Recherche dans l'Industrie et l'Agriculture (FRIA, Belgium). Chemaf society, Kalumine society, Tenke Fungurume Mining S.a.r.l. permitted us the plants and soils collection. We are grateful to Serge Ngoy and JeanJacques Lunzanga for their help in the plants and soils sampling. We are grateful to Petru Jitaru from HydrISE unit (IPLB, France) for his help in the ICP-MS analysis.

We gratefully thank David Houben (IPLB) and Jean-Paul Reynoird (IPLB) for the manuscript pre-review and Kristine French (University of Wollongong, Au), native speaker, for English reviewing. 


\section{References}

Adriano DC, Wenzel WW, Vangronsveld J, Bolan NS (2004) Role of assisted natural remediation in environmental cleanup. Geoderma 122:121-142

Alford ER, Pilon-Smits EA, Paschke MW (2010) Metallophytes - a view from the rhizosphere. Plant Soil 321(12):33-50

Alloway BJ (1995) Heavy Metals in Soils. $2^{\text {nd }}$ Ed. Blackie Academic and Professional, London. pp 368

Avula B, Wan YH, Smillie TJ, Duzgoren-Aydin N, Khan TJ (2010) Quantitative Determination of Multiple Elements in Botanicals and Dietary Supplements Using ICP-MS. Jour Agri Food Chem 58:8887-8894

Baker AJM (1981) Accumulators and excluders - Strategies in the response of plants to heavy metals. J Plant Nutr 3:643-654

Barzanti R, Ozino F, Bazzicalupo M, Gabbrielli R, Galardi F, Gonnelli C, Mengoni A (2007) Isolation and characterization of endophytic bacteria from the nickel hyperaccumulator plant Alyssum bertolonii. Microb Ecol 53:306-316

Brun LA, Maillet J, Richarte J, Herrmann P, Remy JC (1998) Relationships between extractable copper, soil properties and copper uptake by wild plants in vineyard soils. Environ Pollut 102:151-161

Broadley MR, Willey NJ, Wilkins JC, Baker AJM, Mead A, White PJ (2001) Phylogenetic variation in heavy metal accumulation in angiosperms. New Phytol 152:9-27

Brooks RR, Morrison RS, Reeves RD, Dudley TR, Akman Y (1979) Hyperaccumulation of nickel by Alyssum linaeus (Cruciferae). Proc Roy Soc Lond 203:387-403

Brooks RR, Radford CC (1978) Nickel accumulation by European species of the genus Alyssum. Proc Roy Soc Lond 200:217-224

Chaignon V, Bedin F, Hinsinger P (2002) Copper bioavailability and rhizosphere pH changes as affected by nitrogen supply for tomato and oilseed rape cropped on an acidic and calcareous soil. Plant Soil 243:219-228

Chaignon V, Hinsinger P (2003) A Biotest for Evaluating Copper Bioavailability to Plants in a Contaminated Soil. J Environ Qual 32:824-833

Childs CW (1975) Composition of iron-manganese concretions from some New Zealand soils. Geoderma 13:141-152

Chipeng FK, Hermans C, Colinet G, Faucon MP, NgongoLuhembwe M, Meerts P, Verbruggen N (2010) Copper tolerance in the cuprophyte Haumaniastrum katangense (S. Moore) P.A. Duvign. \& Plancke. Plant Soil 328:235244

Collins RN, Kinsela AS (2010) The aqueous phase speciation and chemistry of cobalt in terrestrial environments. Chemosphere 79:763-771

Collins RN, Kinsela AS (2011) Pedogenic factors and measurements of the plant uptake of cobalt. Plant Soil 339:499-512

Dechamps C, Lefèbvre C, Noret N, Meerts P (2007) Reaction norms of life history traits in response to zinc in Thlaspi caerulescens from metalliferous and non metalliferous sites. New Phytol 173:191-198

Duvigneaud P (1958) The vegetation of Katanga and its metalliferous soils. Bull Soc Roy Bot Belg 90:127-286

Duvigneaud P (1959) Plantes cobaltophytes dans le Haut Katanga. Bull Soc Roy Bot Belg 91:111-134

Duvigneaud P, Denaeyer- De Smet S (1963) Cuivre et vegetation au Katanga. Bull Soc Roy Bot Belg 96:92-231 
Ernst W (1974) Schwermetalvegetation der Erde.G. Fisher Verlag, Stuttgart.

Ernst W (1990) Mine vegetation in Europe. In: Shaw JA (ed) Heavy metal tolerance in plants: evolutionary aspects vol 18. CRC, New York, 21-38

Escarre J, Lefebvre C, Frerot H, Mahieu S, Noret N (2013) Metal concentration and metal mass of metallicolous, non metallicolous and serpentine Noccaea caerulescens populations, cultivated in different growth media. Plant Soil 370:197-221

Fageria NK, Wright RJ, Baligar VC, Sousa CMR (1991) Characterization of physical and chemical properties of varzea soils of Goias State of Brazil. Commun Soil Sci Plant Anal 22:1631-1646

Faucon MP, Colinet G, Jitaru P, Verbruggen N, Shutcha M, Mahy G, Meerts P, Pourret O (2011) Relation between Cobalt Fractionation and its Accumulation in Metallophytes from South Central Africa. Mineral Mag $75: 832$

Faucon MP, Colinet G, Mahy G, NgongoLuhembwe M, Verbruggen N, Meerts P (2009) Soil influence on Cu and Co uptake and plant size in the cuprophytes Crepidorhopalon perennis and C. tenuis (Scrophulariaceae) in SC Africa. Plant Soil 317:201-212

Faucon MP, Chipeng F, Verbruggen N, Mahy G, Collinet G, Shutcha M, Pourret O, Meerts P (2012) Copper tolerance and accumulation in two cuprophytes of South Central Africa: Crepidorhopalon perennis and C. tenuis (Linderniaceae). Environ Exp Bot 84:11-16

Faucon MP, Meersseman A, Shutcha MN, Mahy G, Luhembwe MN, Malaisse F, Meerts P (2010) Copper endemism in the Congolese flora: a database of copper affinity and conservational value of cuprophytes. Plant Ecol Evol 143:5-18

Faucon MP, Shutcha M, Meerts P (2007) Revisiting copper and cobalt concentrations in supposed hyperaccumulators from SC Africa: influence of washing and metal concentrations in soil. Plant Soil 301:29-36

Faucon MP, Tshilong BM, Rossum F, Meerts P, Decocq G, Mahy G (2012) Ecology and Hybridization Potential of Two Sympatric Metallophytes, the Narrow Endemic Crepidorhopalon perennis (Linderniaceae) and its More Widespread Congener C. tenuis. Biotropica44:454-462

Frerot H, Faucon MP, Willems G, Godé C, Courseaux A, Darracq A, Verbruggen N, Saumitou-Laprade P (2010) Genetic architecture of zinc hyperaccumulation in Arabidopsis halleri: the essential role of QTL $\times$ environment interactions. New Phytol 187:355-367

Fomina MA, Alexander IJ, Colpaert JV, Gadd GM (2005) Solubilization of toxic metal minerals and metal tolerance of mycorrhizal fungi. Soil Biol Biochem 37:851-866

Gills TE (1995) Standard reference material 1537a - Tomatoe leaves - Certificate of Analysis. National Institute of Standards and Technology pp 5

Harter RD, Naidu R (2001) An assessment of environmental and solution parameter impact on trace-metal sorption by soils. Soil Sci Soc Am J 65:597-612

Hanikenne M, Nouet C (2011) Metal hyperaccumulation and hypertolerance: a model for plant evolutionary genomics. Curr Opin Plant Biol 14:252-259

Hinsinger P (2001) Bioavailability of soil inorganic P in the rhizosphere as affected by root-induced chemical changes: a review. Plant Soil 237:173-195

Hinsinger P, Courchesne F (2008) Biogeochemistry of metals and metalloids at the soil-root interface 268-312. In: Biophysico-Chemical Processes of Heavy Metals and Metalloids in Soil Environment. Edited by A Violante, PM Huang, GM Gadd (2008) John Wiley and Sons, Inc

Hinsinger P, Gobran GR, Gregory PJ, Wenzel WW (2005) Rhizosphere geometry and heterogeneity arising from root-mediated physical and chemical processes. New Phytol 168:293-303 
Hinsinger P, Plassard C, Tang C, Jaillard B (2003) Origins of root-induced pH changes in the rhizosphere and their responses to environmental constraints: a review. Plant Soil 248:43-59

Houben D, Sonnet Ph (2012) Zinc mineral weathering as affected by plant roots. Appl Geochem 27:1587-1592

Ilunga wa Ilunga E, Seleck M, Colinet G, Faucon MP, Meerts P, Mahy G (2013) Small-scale diversity of plant communities and distribution of species niches on a copper rock outcrop in Upper Katanga, DR Congo. Plant Ecol Evol 146:173-182

Kabagale AC, Cornu B, van Vliet F, Meyer CL, Mergeay M, LumbuSimbi JB, Droogmans L, Vander Wauven C, Verbruggen N (2010) Diversity of endophytic bacteria from the cuprophytes Haumaniastrum katangense and Crepidorhopalon tenuis. Plant Soil 334:461-474

Kabata-Pendias A, Pendias H (2001) Trace elements in soils and plants. $3^{\text {rd }}$ ed. CRC Press. Boca Raton, London, New-York, Washington D.C. pp 403

Knight B, Zaho FJ, McGrath SP, Shen ZG (1997) Zinc and cadmium uptake by the hyperaccumulator Thlaspi caerulescens in contaminated soils and its effects on the concentration and chemical speciation of metals in soil solution. Plant Soil 197:71-78

Krämer U (2010) Metal hyperaccumulation in plants. Annu Rev Plant Biol 61:517-534

Krishnamurti GSR, Naidu R (2002) Solid-solution speciation and phytoavailability of copper and zinc in soils. Environ Sci Technol 36:2645-2651

Küpper H, Götz B, Mijovilovich A, Küpper FC, Meyer-Klaucke W (2009) Complexation and toxicity of copper in higher plants: I. Characterization of copper accumulation, speciation, and toxicity in Crassula helmsii as a new copper accumulator. Plant Physiol 151:702-714

Lavilla I, Filgueiras AV, Bendicho C (1999) Comparison of Digestion Methods for Determination of Trace and Minor Metals in Plant Samples. J Agr Food Chem 47:5072-5077

Li Z, McLaren RG, Metherell AK (2004) The availability of native and applied soil cobalt to ryegrass in relation to soil cobalt and manganese status and other soil properties. New Zeal J Agr Res 47:33-43

Lofts S, Tipping E (1998) An assemblage model for cation binding by natural particulate matter. Geochim Cosmochim Acta 62:2609-2625

Luo D, Zheng H, Chen Y, Wang G, Fenghua D (2010) Transfer characteristics of cobalt from soil to crops in the suburban areas of Fujian Province, southeast China. J Environ Manage 91:2248-2253

Macnair MR (2003) The hyperaccumulation of metal by plants. Adv Bot Res 40:63-105

Marschner H (1995) Mineral Nutrition of Higher Plants. Academic Press International, San Diego, CA, USA

McLaren RG, Crawford DV (1973) Studies on soil copper. I. The fractionation of copper in soils. J Soil Sci 24:172-181.

McLaren RG, Lawson DM, Swift RS (1987) The availability to pasture plants of native and applied soil cobalt in relation to extractable soil cobalt and other soil properties. J Sci Food Agric 39:101-112

Morrison RS, Brooks RR, Reeves RD, Malaisse F (1979) Copper and Cobalt uptake by metallophytes from Zaïre. Plant Soil 53:535-539

Nolan AL, Lombi E, McLaughlin MJ (2003) Metal bioaccumulation and toxicity in soils - why bother with speciation? Aust J Chem 56:77-91

Pollard AJ, Powell KD, Harperf A, Smith JAC (2002) The Genetic Basis of Metal Hyperaccumulation in Plants. Plant Sci 21:539-566. 
Poschenreider C, Bech J, Llugany M, Pace A, Fenes E, Barcelo J (2001) Copper in plant species in a copper gradient in Catalonia (North East Spain) and their potential for phytoremédiation. Plant Soil 230:247-256

Pourret O, Dia A, Davranche M, Gruau G, Henin O, Angee M (2007) Organo-colloidal control on major- and trace-element partitioning in shallow groundwaters: Confronting ultrafiltration and modeling. App Geochem 22:1568-1582

Rascio N, Navari-Izzo F (2011) Heavy metal hyperaccumulating plants: how and why do they do it? And what makes them so interesting? Plant Sci 180:169-181

Reeves RD (2006) Hyperaccumulation of trace elements by plants. In: Morel JL, Echevarria G, Goncharova N (eds) Phytoremediation of Metal-Contaminated Soils. NATO Science series: IV: earth and environmental sciences vol 68. Springer, New York 193-221

Reeves RD, Baker AJM (2000) Metal-accumulating plants. In: Raskin I, Ensley BD (eds) Phytoremediation of toxic metals. Wiley, New York 193-221

Saad L, Parmentier I, Colinet G, Malaisse F, Faucon MP, Meerts P, Mahy G (2012) Investigating the vegetationsoil relationships on the copper-cobalt rock outcrops of Katanga (DR Congo), an essential step in a biodiversity conservation plan. Restor Ecol 20:405-415

Séleck M, Bizoux JP, Colinet G, Faucon MP, Guillaume A, Meerts P, Piqueray J, Mahy G (2013) Chemical soil factors influencing plant assemblages along copper-cobalt gradients: implications for conservation and restoration. Plant Soil 373:455-469

Stumm W, Morgan JJ (1996) Aquatic chemistry, Chemical Equilibria and Rates in Natural Waters, $3^{\text {rd }}$ ed. John Wiley \& Sons, Inc, New York pp1022

Tipping E (1994) WHAM - a chemical equilibrium model and computer code for waters, sediments and soils incorporating a discrete site/electrostatic model of ion-binding by humic substances. Comp Geosci 20:973-1023

Tipping E (1998) Humic ion-binding model VI: an improved description of the interactions of protons and metal ions with humic substances. Aquat Geochem 4:3-48

Toler HD, Morton JB, Cumming JR (2005) Growth and metal accumulation of Mycorrhizal sorghum exposed to elevated copper and zinc. Water Air Soil Poll 164:155-172

Tongtavee N, Shiowatana J, McLaren RG, Buanuam J (2005) Evaluation of distribution and chemical associations between cobalt and manganese in soils by continuous-flow sequential extraction. Commun Soil Sci Plan 36:2839-2855

Van der Ent A, Baker AJM, Reeves RD, Pollard AJ, Schat H (2013) Hyperaccumulators of metal and metalloid trace elemens: Facts and fiction. Plant Soil 362:319-334

Villafort Carvalho M, Amaral DC, Guilheme LRG, Aarts MGM (2013) Gomphrena claussenii, the first South American matallophyte species with indicator-like $\mathrm{Zn}$ and $\mathrm{Cd}$ accumulation and extreme metal tolerance. Front Plant Sci. 4: pp10 DOI 10.3389/fpls.2013.00180

Wenzel WW (2009) Rhizosphere processes and management in plant-assisted bioremediation (phytoremediation) of soils. Plant Soil 321:385-408

Whitehead DC (2000) Nutrient elements in grassland. Soil-plant-animal relationships. CAB International, Wallingford, UK, $369 \mathrm{pp}$ 
Table $2 \mathrm{Cu} / \mathrm{Co}$ mean fractionation among seven sites $(\%)$ according to the total mean $\mathrm{Cu} / \mathrm{Co}$ concentration in soil $\left(\mathrm{mg}_{\mathrm{kg}} \mathrm{kg}^{-1}\right)$ F5: $n=20 ; G 2: n=20 ; E: n=20 ; N m: n=35 ;$ Ka: $n=17$; VK: $n=16$; Ru: $n=18$. ***: $p<0.001, * *: p<0.01, *: p<0.05$, $\mathrm{NS}=$ non-significant. For columns, variables with the same letter above are not significantly different. For lines, $\mathrm{Cu}$ and $\mathrm{Co}$ fractions (considered separately) with the same letter below are not significantly different (results of post-hoc multiple comparison, Tukey HSD test). Free $=$ ionic form, $-\mathrm{MnOx}=$ bound to manganese oxides, $\mathrm{FeOx}=$ bound to iron oxides, $-\mathrm{OM}=$ bound to organic matter, $S D=$ standard deviation

Table 3 Correlation between soil factors and $\mathrm{Cu}$ and $\mathrm{Co}$ concentrations in shoots of Anisopappus chinensis $(n=79)$ and Crepidorhopalon tenuis $(n=67)$ : Pearson correlation coefficients using log-transformed data 
Table 1

\begin{tabular}{|c|c|c|c|c|}
\hline Site & Habitat description & $\begin{array}{l}\text { Altitude } \\
\text { (m) }\end{array}$ & $\begin{array}{l}\text { Coordinates } \\
\text { (GCSWGS84 DD) }\end{array}$ & Species sampled \\
\hline Fungurume 5 (F5) & $\begin{array}{l}\text { Natural Cu-Co hill not disturbed } \\
\text { by mining. Sampled on } \\
\text { grassland. }\end{array}$ & 1,300 & $\begin{array}{l}\text { S } 10,61777 \\
\text { E } 26,29112\end{array}$ & A. chinensis \\
\hline Goma 2 (G2) & $\begin{array}{l}\text { Natural Cu-Co hill locally } \\
\text { disturbed by mining. Sampled on } \\
\text { grassland. }\end{array}$ & 1,300 & $\begin{array}{l}\text { S } 10,59966 \\
\text { E } 26,13894\end{array}$ & A. chinensis \\
\hline Etoile (E) & $\begin{array}{l}\text { Former natural Cu-Co hill } \\
\text { completely disturbed by mining. } \\
\text { Open pit. Sampled on remaining } \\
\text { substratum. }\end{array}$ & 1,280 & $\begin{array}{l}\text { S } 11,63562 \\
\text { E } 27,58449\end{array}$ & A. chinensis \\
\hline Niamumenda (Nm) & $\begin{array}{l}\text { Natural Cu-Co hill locally } \\
\text { disturbed by mining. Sampled on } \\
\text { grassland locally disturbed. }\end{array}$ & 1,340 & $\begin{array}{l}\text { S } 11,60492 \\
\text { E } 27,29400\end{array}$ & $\begin{array}{l}\text { A. chinensis } \\
\text { C. tenuis }\end{array}$ \\
\hline Kalabi (Ka) & $\begin{array}{l}\text { Natural Cu-Co hill locally } \\
\text { disturbed by mining. Open pit. } \\
\text { Sampled on grassland locally } \\
\text { disturbed. }\end{array}$ & 1,200 & $\begin{array}{l}\text { S } 10,78168 \\
\text { E } 26,74053\end{array}$ & C. tenuis \\
\hline Vallée Karavia (VK) & $\begin{array}{l}\text { Anthropogenic site: soil } \\
\text { contaminated by atmospheric } \\
\text { fallout from ore-smelter, moist. }\end{array}$ & 1,230 & $\begin{array}{l}\text { S } 11,67270 \\
\text { E } 27,43091\end{array}$ & C. tenuis \\
\hline Ruashi (Ru) & $\begin{array}{l}\text { Anthropic site: recolonization of } \\
\text { Mine deposits. Sampled on } \\
\text { remaining substratum. }\end{array}$ & 1,300 & $\begin{array}{l}\text { S } 11,62645 \\
\text { E } 27,56328\end{array}$ & C. tenuis \\
\hline
\end{tabular}


Table 2

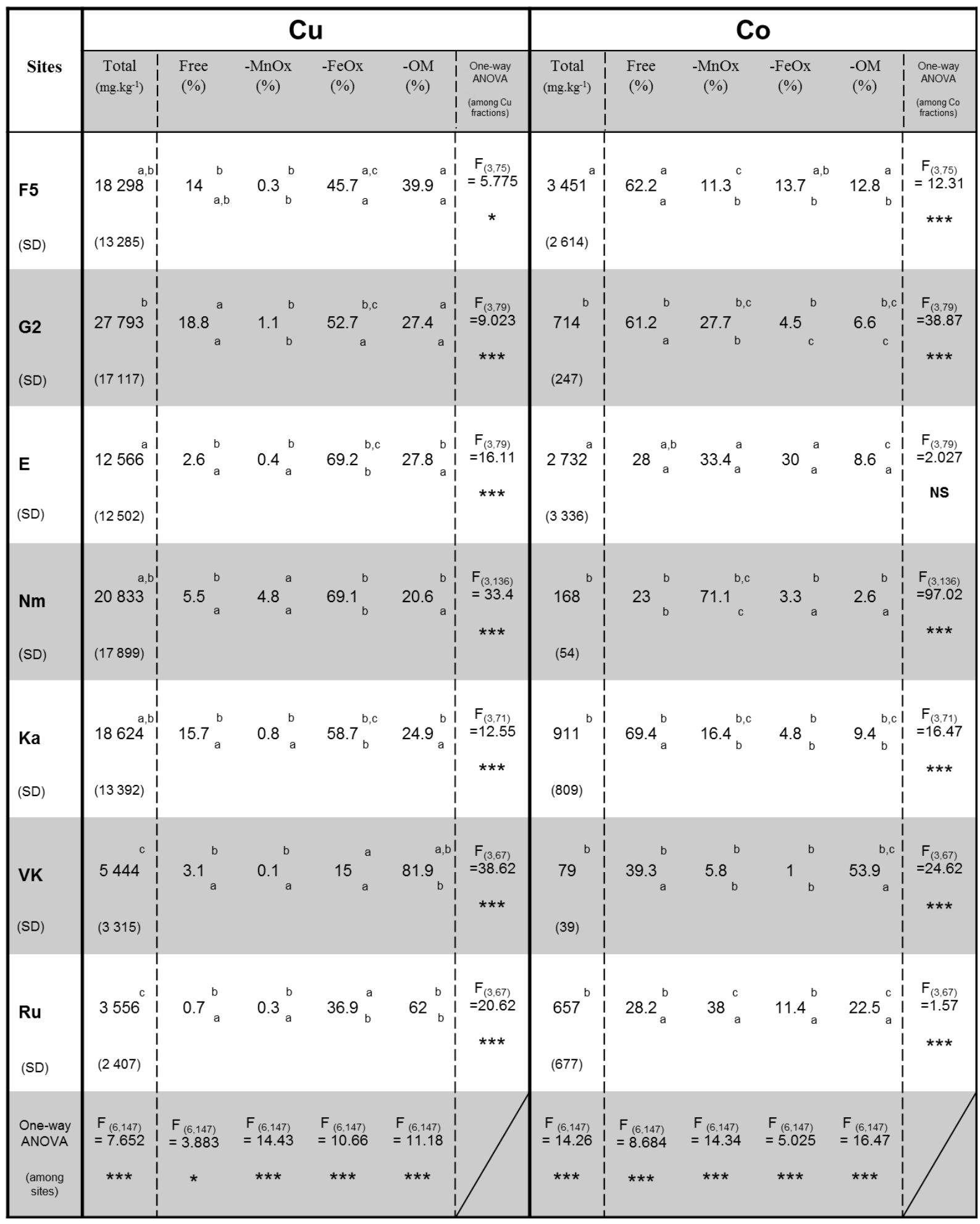




\begin{tabular}{|c|c|c|c|c|}
\hline & \multicolumn{2}{|c|}{ A. chinensis } & \multicolumn{2}{|c|}{ C.tenuis } \\
\hline & $\mathrm{Cu}$ (shoot) & Co (shoot) & $\mathrm{Cu}$ (shoot) & Co (shoot) \\
\hline$[\mathrm{Cu}]$ total & $0.188 \mathrm{NS}$ & -0.192 NS & $0.513^{* * *}$ & $0.092 \mathrm{NS}$ \\
\hline$[\mathrm{Cu}]$ free & $0.111 \mathrm{NS}$ & $0.071 \mathrm{NS}$ & $0.497 * * *$ & 0.075 NS \\
\hline$[\mathrm{Cu}-\mathrm{MnOx}]$ & $0.395 * * *$ & $-0.535 * * *$ & $0.761 * * *$ & $-0.195 \mathrm{NS}$ \\
\hline$[\mathrm{Cu}]$ free+ $[\mathrm{Cu}-\mathrm{MnOx}]$ & $0.207 \mathrm{NS}$ & $-0.135 N S$ & $0.566 * * *$ & $-0.007 \mathrm{NS}$ \\
\hline$[\mathrm{Cu}-\mathrm{FeOx}]$ & $0.282 *$ & $-0.440 * * *$ & $0.603 * * *$ & $0.071 \mathrm{NS}$ \\
\hline$[\mathrm{Cu}]$ free $+[\mathrm{Cu}-\mathrm{FeOx}]$ & 0.204 NS & $-0.313 * *$ & $0.592 * * *$ & $0.085 \mathrm{NS}$ \\
\hline$[\mathrm{Cu}-\mathrm{OM}]$ & $-0.138 \mathrm{NS}$ & $0.404 * * *$ & 0.086 NS & $0.295 *$ \\
\hline$[\mathrm{Cu}]$ free $+[\mathrm{Cu}-\mathrm{OM}]$ & $-0.087 \mathrm{NS}$ & $0.314^{* *}$ & $0.232 \mathrm{NS}$ & $0.268 *$ \\
\hline$[\mathrm{Co}]$ total & $-0.339 * *$ & $0.772 * * *$ & $0.245 *$ & $0.475 * * *$ \\
\hline$[\mathrm{Co}]$ free & $-0.311 * *$ & $0.804 * * *$ & 0.219 NS & $0.567 * * *$ \\
\hline$[\mathrm{Co}-\mathrm{MnOx}]$ & -0.073 NS & $0.280 *$ & $0.452 * * *$ & 0.137 NS \\
\hline$[\mathrm{Co}]$ free $+[\mathrm{Co}-\mathrm{MnOx}]$ & $-0.270 *$ & $0.725 * * *$ & $0.374 * *$ & $0.392 * *$ \\
\hline$[\mathrm{Co}-\mathrm{FeOx}]$ & $-0.313 * *$ & $0.464 * * *$ & $0.055 \mathrm{NS}$ & $0.379 * *$ \\
\hline$[\mathrm{Co}]$ free $+[\mathrm{Co}-\mathrm{FeOx}]$ & $-0.376 * * *$ & $0.812 * * *$ & $0.183 \mathrm{NS}$ & $0.568 * * *$ \\
\hline$[\mathrm{Co}-\mathrm{OM}]$ & $-0.405 * * *$ & $0.899 * * *$ & $-0.405 * * *$ & $0.644 * * *$ \\
\hline$[\mathrm{Co}]$ free $+[\mathrm{Co}-\mathrm{OM}]$ & $-0.333 * *$ & $0.836 * * *$ & $0.055 \mathrm{NS}$ & $0.638 * * *$ \\
\hline $\mathrm{pH}$ & -0.069 NS & -0.101 NS & $0.401 * * *$ & 0.202 NS \\
\hline OM content & $-0.336 * *$ & $0.567 * * *$ & $-0.395 * * *$ & 0.219 NS \\
\hline [Mn] total & $0.507 * * *$ & $-0.646 * * *$ & $0.652 * * *$ & -0.054 NS \\
\hline$[\mathrm{Fe}]$ total & $0.419 * * *$ & $-0.554 * * *$ & $0.236 \mathrm{NS}$ & -0.053 NS \\
\hline [Ca] total & $-0.333 * *$ & $0.465 * * *$ & $-0.443 * *$ & $0.244 *$ \\
\hline$[\mathrm{Mg}]$ total & 0.114 NS & $-0.390 * *$ & $0.530 * * *$ & $-0.116 \mathrm{NS}$ \\
\hline
\end{tabular}

757

758

759

760

761

762

763

764

765

766

767

768

769

770

771

772

773

774

775

776

777

778

779

780

781 
Fig.1 Copper and cobalt concentrations accumulated in shoots of four populations of Anisopappus chinensis and four populations of Crepidorhopalon tenuis Sites are designated as follow: E=Etoile; Nm=Niamumenda; G2=Goma2; F5=Fungurume 5; Ka=Kalabi; $\mathrm{VK}=$ Vallée Karavia; $\mathrm{Ru}=\mathrm{Ruashi}$. Ac=Anisopappus chinensis; $\mathrm{n}=79 ; \mathrm{Ct}=$ Crepidorhopalon tenuis; $\mathrm{n}=67$. Error bars=standard deviation. For each species, there are no significant differences between populations with the same letter (results of one-way ANOVA followed by post-hoc multiple comparison, Tukey HSD test).

Fig.2 Relationships between element concentrations in plants and in soils

$\mathbf{a} \mathrm{Cu}$ in plant and total $\mathrm{Cu}$ in soil $\mathbf{b} \mathrm{Co}$ in plant and total $\mathrm{Co}$ in soil $\mathbf{c} \mathrm{Cu}$ in plant and free $\mathrm{Cu}$ in soil $\mathbf{d} \mathrm{Co}$ in plant and free $\mathrm{Co}$ in soil $\mathbf{e} \mathrm{Cu}$ in plant and bound to $\mathrm{MnOx} \mathrm{Cu} \mathbf{f} \mathrm{Co}$ in plant and bound to OM Co (A. chinensis: $\mathrm{n}=79$; C. tenuis: $\mathrm{n}=67$ ) 


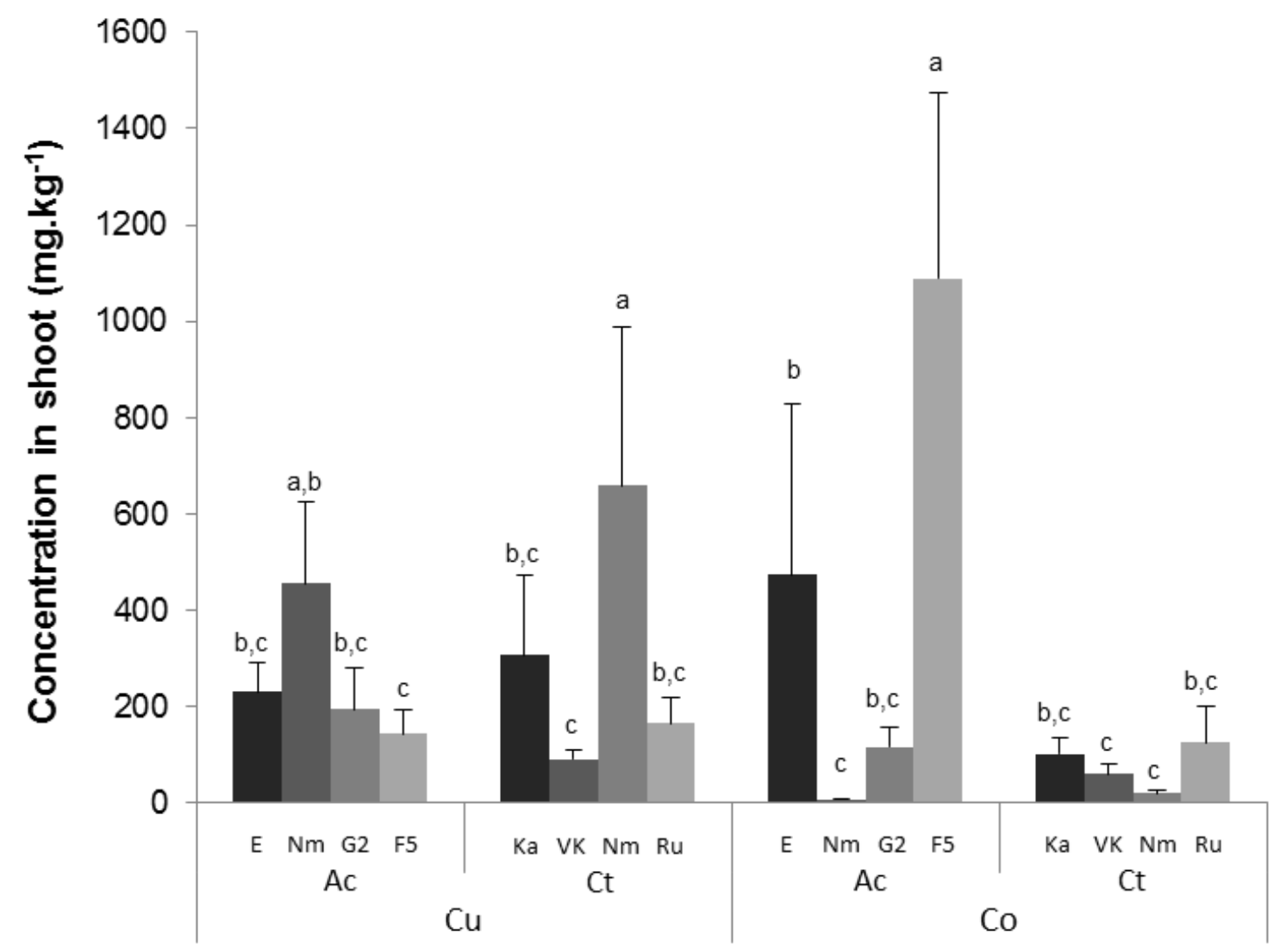


Fig.2
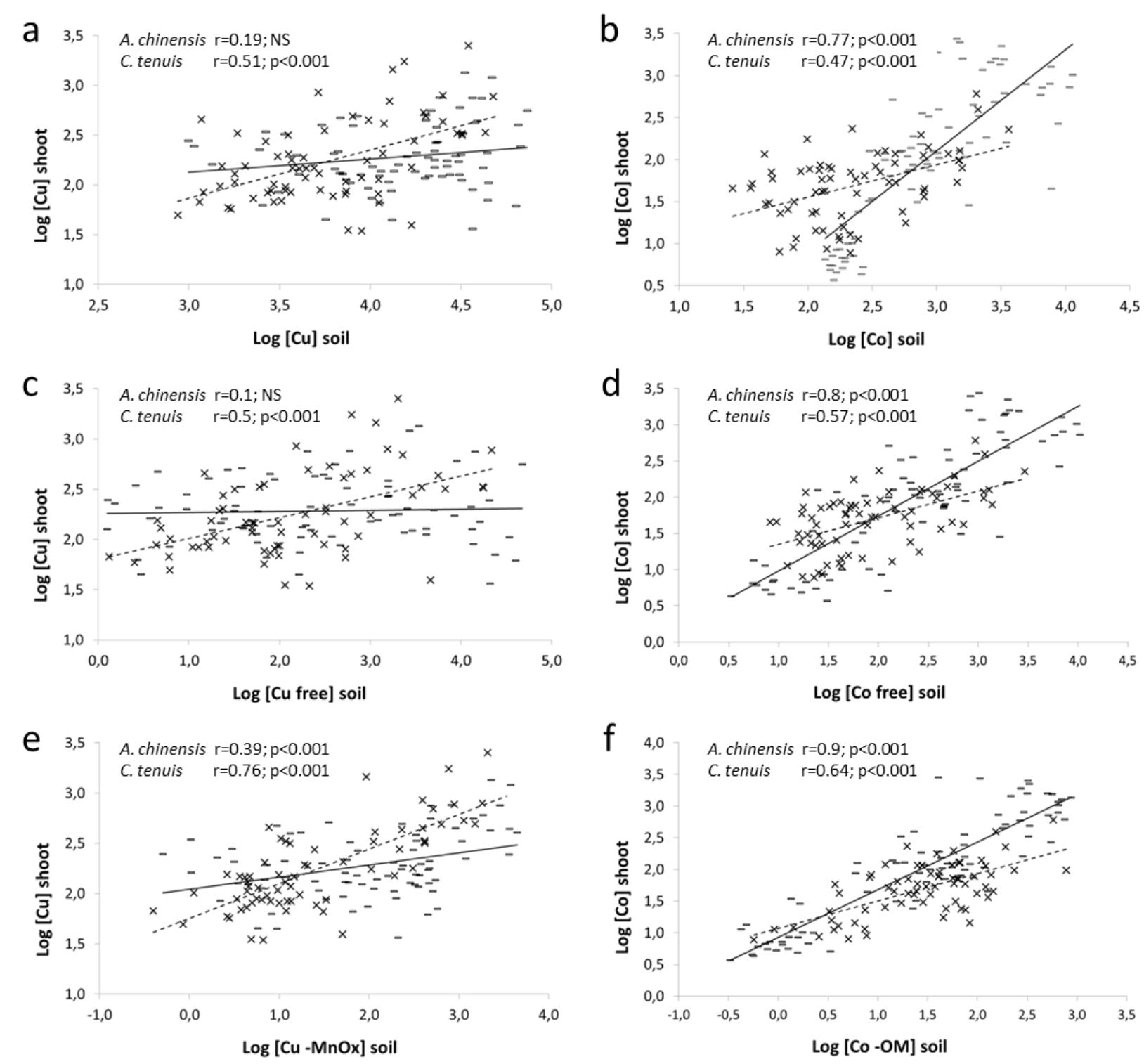
Table S1 Total concentrations of elements, $\mathrm{pH}$ and organic matter in soils for seven metalliferous sites in Katanga (Dem. Rep. Congo). F5, Fungurume $5(\mathrm{n}=20)$; G2, Goma 2 ( $\mathrm{n}=20)$; E, Etoile ( $\mathrm{n}=20)$; Nm, Niamumenda ( $\mathrm{n}=35)$; Ka, Kalabi ( $\mathrm{n}=17)$; VK, Vallée Karavia ( $\mathrm{n}=16)$; Ru, Ruashi $(\mathrm{n}=18)$.

\begin{tabular}{|c|c|c|c|c|c|c|c|}
\hline Mean & $\mathbf{E}$ & $\mathrm{Nm}$ & G2 & F5 & $\mathrm{Ka}$ & VK & $\mathbf{R u}$ \\
\hline $\begin{array}{c}\mathrm{Cu}\left(\mathrm{mg} \cdot \mathrm{kg}^{-1}\right) \\
(\mathrm{SD})\end{array}$ & $\begin{array}{l}12,566 \\
(12,502)\end{array}$ & $\begin{array}{l}20,833 \\
(17,899)\end{array}$ & $\begin{array}{l}27,793 \\
(17,117)\end{array}$ & $\begin{array}{l}18,298 \\
(13,285)\end{array}$ & $\begin{array}{l}18,624 \\
(13,392)\end{array}$ & $\begin{array}{l}5,444 \\
(3,315)\end{array}$ & $\begin{array}{l}3,556 \\
(2,407)\end{array}$ \\
\hline $\begin{array}{c}\text { Co }\left(\mathrm{mg} \cdot \mathrm{kg}^{-1}\right) \\
(\mathrm{SD})\end{array}$ & $\begin{array}{l}2,732 \\
(3,336)\end{array}$ & $\begin{array}{l}168 \\
(54)\end{array}$ & $\begin{array}{l}714 \\
(247)\end{array}$ & $\begin{array}{l}3,451 \\
(2,614)\end{array}$ & $\begin{array}{l}911 \\
(809)\end{array}$ & $\begin{array}{l}79 \\
(39)\end{array}$ & $\begin{array}{l}657 \\
(677)\end{array}$ \\
\hline $\begin{array}{l}\mathrm{pH} \\
\quad(\mathrm{SD})\end{array}$ & $\begin{array}{l}6.37 \\
(0.64)\end{array}$ & $\begin{array}{l}5.70 \\
(0.57)\end{array}$ & $\begin{array}{l}6.04 \\
(0.17)\end{array}$ & $\begin{array}{l}6.18 \\
(0.58)\end{array}$ & $\begin{array}{l}5.60 \\
(0.31)\end{array}$ & $\begin{array}{l}4.99 \\
(0.23)\end{array}$ & $\begin{array}{l}5.19 \\
(0.25)\end{array}$ \\
\hline $\begin{array}{l}\mathrm{OM}(\%) \\
(\mathrm{SD})\end{array}$ & $\begin{array}{l}6,26 \\
(2,75)\end{array}$ & $\begin{array}{l}4,57 \\
(2,05)\end{array}$ & $\begin{array}{l}8,60 \\
(2,68)\end{array}$ & $\begin{array}{l}11,44 \\
(5,30)\end{array}$ & $\begin{array}{l}5,28 \\
(1,93)\end{array}$ & $\begin{array}{l}9,38 \\
(4,25)\end{array}$ & $\begin{array}{l}12,73 \\
(3,41)\end{array}$ \\
\hline $\begin{array}{c}\mathrm{Mn}\left(\mathrm{mg} \cdot \mathrm{kg}^{-1}\right) \\
\text { (SD) }\end{array}$ & $\begin{array}{l}2,625 \\
(1,852)\end{array}$ & $\begin{array}{l}5,710 \\
(4,697)\end{array}$ & $\begin{array}{l}1,600 \\
(449)\end{array}$ & $\begin{array}{l}1,047 \\
(223)\end{array}$ & $\begin{array}{l}1,070 \\
(806)\end{array}$ & $\begin{array}{l}64 \\
(37)\end{array}$ & $\begin{array}{l}1,023 \\
(926)\end{array}$ \\
\hline $\begin{array}{c}\mathrm{Fe}\left(\mathrm{mg} \cdot \mathrm{kg}^{-1}\right) \\
(\mathrm{SD})\end{array}$ & $\begin{array}{l}42,305 \\
(11,460)\end{array}$ & $\begin{array}{l}48,534 \\
(21,237)\end{array}$ & $\begin{array}{l}27,745 \\
(5,753)\end{array}$ & $\begin{array}{r}21,315 \\
(9,387)\end{array}$ & $\begin{array}{l}35,250 \\
(11,309)\end{array}$ & $\begin{array}{l}19,610 \\
(9,654)\end{array}$ & $\begin{array}{l}51,060 \\
(9,128)\end{array}$ \\
\hline $\begin{array}{c}\mathrm{Zn}\left(\mathrm{mg}^{\mathrm{kg}} \mathrm{kg}^{-1}\right) \\
(\mathrm{SD})\end{array}$ & $\begin{array}{l}123 \\
(129)\end{array}$ & $\begin{array}{l}144 \\
(91)\end{array}$ & $\begin{array}{l}56 \\
(24)\end{array}$ & $\begin{array}{l}27 \\
(10)\end{array}$ & $\begin{array}{l}190 \\
(121)\end{array}$ & $\begin{array}{l}388 \\
(195)\end{array}$ & $\begin{array}{l}152 \\
(67)\end{array}$ \\
\hline $\begin{array}{c}\mathrm{Mg}\left(\mathrm{mg} \cdot \mathrm{kg}^{-1}\right) \\
(\mathrm{SD})\end{array}$ & $\begin{array}{l}49,510 \\
(44,430)\end{array}$ & $\begin{array}{l}48,147 \\
(20,448)\end{array}$ & $\begin{array}{l}41,595 \\
(7,260)\end{array}$ & $\begin{array}{l}36,875 \\
(22,029)\end{array}$ & $\begin{array}{l}22,700 \\
(25,755)\end{array}$ & $\begin{array}{c}2,084 \\
(470)\end{array}$ & $\begin{array}{l}27,591 \\
(21,195)\end{array}$ \\
\hline $\begin{array}{c}\mathrm{Ca}\left(\mathrm{mg} \cdot \mathrm{kg}^{-1}\right) \\
(\mathrm{SD})\end{array}$ & $\begin{array}{l}642 \\
(275)\end{array}$ & $\begin{array}{l}416 \\
(138)\end{array}$ & $\begin{array}{l}595 \\
(160)\end{array}$ & $\begin{array}{l}1,945 \\
(1,710)\end{array}$ & $\begin{array}{l}694 \\
(302)\end{array}$ & $\begin{array}{l}578 \\
(151)\end{array}$ & $\begin{array}{l}736 \\
(295)\end{array}$ \\
\hline $\begin{array}{c}\mathrm{K}\left(\mathrm{mg} \cdot \mathrm{kg}^{-1}\right) \\
(\mathrm{SD})\end{array}$ & $\begin{array}{l}12,940 \\
(10,375)\end{array}$ & $\begin{array}{l}7,395 \\
(6,411)\end{array}$ & $\begin{array}{l}6,155 \\
(3,431)\end{array}$ & $\begin{array}{l}6,085 \\
(7,973)\end{array}$ & $\begin{array}{l}13,300 \\
(13,577)\end{array}$ & $\begin{array}{l}5,734 \\
(1,776)\end{array}$ & $\begin{array}{l}6,766 \\
(3,363)\end{array}$ \\
\hline
\end{tabular}

